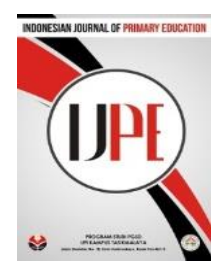

\title{
Penggunaan TIK sebagai Sumber dan Media Pembelajaran Inovatif di Sekolah Dasar
}

\author{
Suci Zakiah Dewi ${ }^{1}$, Irfan Hilman ${ }^{2}$ \\ Universitas Garut \\ *Corresponding author: sucizakiahdewi@uniga.ac.id, irfanhilman@uniga.ac.id \\ Diterima 20 Agustus 2018; Direview 18 September 2018; Diterima 15 Oktober 2018 \\ Diterbitkan online 28 Desember 2018
}

\begin{abstract}
The application of ICT as a learning source andlearning media can be through the utilization of computer devices as an innovative learning source and media. It is expected that with the use of these sources and media can stimulate students' thoughts, feelings, interests also concerns in such a way that the learning process can run well. In addition, the learning process will be more effective because the use of ICT as a source and learning media enables to overcoming the obstacles in the process of communicating between teachers and students. The use of ICT as a learning media can be through the use of computer devices as innovative learning media. It is expected that the use of this media can stimulate the thoughts, feelings, interests and attention of the students in such a way that the learning process can run well. In other hand, the learning process will be more effective because the use of ICT as a learning media enables to solve the obstacles in the process of communication between teachers and students such as physiological, psychological, cultural, and environmental barriers. Other types of resources and ICT-based learning media that can be used by elementary school teachers in the learning process, among others are (1) Computers, (2) LCD Projector, (3) Internet, (4) Learning CDs, (5) E- mail, and (6) Percentage of Power Point. In terms of increasing the mastery of ICT skills for teachers, some of them can do this by participating in training or seminars on ICTs, complementing ICTbased facilities and infrastructure to support other learning by conducting comparative studies to schools that are seen as more advanced in their ICT fields.
\end{abstract}

Keywords: Information and Communication Technology; Learning Resources; Learning Media; Elementary Schools.

\begin{abstract}
Abstrak
Penggunaan TIK sebagai sumber dan media pembelajaran dapat melalui pemanfaatan perangkat komputer sebagai sumber dan media pembelajaran yang inovatif. Diharapkan dengan penggunaan sumber dan media ini dapat merangsang pikiran, perasaan, minat serta perhatian peserta didik sedemikian rupa sehingga proses pembelajaran dapat berjalajan dengan baik. Selain itu, proses pembelajaran akan lebih efektif karena penggunaan TIK sebagai sumber dan media pembelajaran memungkinkan teratasinya hambatan dalam proses komunikasi guru dengan peserta didik. Penggunaan TIK sebagai media pembelajaran dapat melalui pemanfaatan perangkat komputer sebagai media pembelajaran yang inovatif. Diharapkan dengan penggunaan media ini dapat merangsang pikiran, perasaan, minat serta perhatian peserta didik sedemikian rupa sehingga proses pembelajaran dapat berjalajan dengan baik. Selain itu, proses pembelajaran akan lebih efektif karena penggunaan TIK sebagai media pembelajaran memungkinkan teratasinya hambatan dalam proses komunikasi guru dengan peserta didik seperti hambatan fisiologis, psikologis, kultural, dan lingkungan. Jenis-jenis sumber dan media pembelajaran berbasis TIK lainnya yang dapat dimanfaatkan oleh guru sekolah dasar dalam proses pembelajaran anatara lain yaitu (1) Komputer, (2) LCD Projector, (3) Internet, (4) CD Pembelajaran, (5) E-mail, dan (6) Persentasi Power Point. Dalam hal meningkatkan kemampuan penguasaan TIK bagi guru dapat dilakukan beberapa diantaranya dengan mengikuti kegiatan pelatihan atau seminar mengenai TIK, melengkapi sarana dan parasarana berbasis TIK guna menunjang pembelajaran selain itu dengan mengadakan studi banding ke sekolah yang dipandang lebih maju dalam bidang TIKnya.
\end{abstract}

Kata kunci : Teknologi Informasi Dan Komunikasi; Sumber Belajar; Media Pembelajaran; Sekolah Dasar. 



\section{PENDAHULUAN}

Teknologi informasi dan komunikasi (TIK) mengalami perkembangan yang amat pesat sehingga membawa perubahan yang signifikan dalam percepatan dan inovasi penyelenggaraan pendidikan di berbagai Negara. Melalui pemanfaatan TIK kita dapat meningkatkan mutu pendidikan, yaitu dengan cara membuka dengan lebar terhadap akses ilmu pengetahuan dan penyelenggaraan pendidikan bermutu. Adanya TIK memberikan jangkauan yang luas, cepat, efektif, dan efesien terhadap penyebarluasan informasi ke berbagai penjuru dunia.

Penggunaan TIK di dunia pendidikan menyebabkan perubahan mendasar dalam hal cara mengajar guru, belajar peserta didik, dan manajemen sekolah dari yang ada sebelumnya. TIK menyebabkan perubahan dalam hal peran guru yang tidak sekedar sebagai sumber dan pemberi ilmu pengetahuan, namun menjadikannya sebagai seorang fasilitator bahkan teman belajar peserta didik. Karenanya guru dapat memberikan pilihan dan tanggung jawab yang besar kepada peserta didik untuk mengalami peristiwa belajar. Dengan peran guru sebagaimana dimaksud, maka peran peserta didik pun mengalami perubahan, dari partisipan pasif menjadi partisipan aktif yang banyak menghasilkan dan berbagi (sharing) pengetahuan/keterampilan serta berpartisipasi sebanyak mungkin sebagaimana layaknya seorang ahli. Disisi lain peserta didik juga dapat belajar secara individu, sebagaimana halnya juga kolaboratif dengan siswa lain.

Peranan TIK dianggap sangat penting dalam dunia pendidikan. Pendidikan suatu bangsa merupakan tolak ukur kemampuan suatu bangsa. Oleh karena itu, penggunaan TIK diharapkan dapat meningkatkan kualitas pendidikan kita. Salah satu cara penggunaan TIK yaitu menjadikan TIK sebagai sumber dan media pembelajaran yang inovatif. Sehingga proses pembelajaran akan lebih menarik dan hasilnya terasa bermakna oleh peserta didik. Guru sebagai tenaga pengajar yang profesional harus tahu dan paham akan pentingnya TIK dalam pembelajaran pada saat ini.

\section{KAJIAN PUSTAKA}

\section{Teknologi Informasi dan Komunikasi (TIK)}

Teknologi Informasi dan Komunikasi mencakup dua aspek, Menurut puskur kemendiknas (dalam Rusman, dkk (2011) yaitu:

1. Teknologi Informasi adalah meliputi segala hal yang berkaitan dengan proses, penggunaan sebagai alat bantu, manipulasi, dan pengelolaan informasi.

2. Teknologi komunikasi adalah segala hal yang berkaitan dengan penggunaan alat bantu untuk memproses dan mentransfer data dari perangkat yang satu ke lainya.

Maka, teknologi informasi dan teknologi komunikasi adalah suatu kesatuan yang tidak terpisahkan yang mengandung pengertian luas 
tentang segala kegiatan yang terkait dengan pemrosesan, manipulasi, pengelolaan dan transfer atau pemindahan informasi antar media. Pengertian lain dari Teknologi Informasi dan Komunikasi (TIK) adalah beragam set alat teknologi dan sumber daya yang digunakan untuk berkomunikasi dan menciptakan, menyebarkan, menyimpan dan mengelola Informasi. Definisi yang luas ini TIK termasuk teknologi radio, televisi, video, DVD, telepon, sistem satelit, komputer dan perangkat keras jaringan dan perangkat lunak; serta peralatan dan jasa terkait dengan teknologi ini, seperti videoconferencing dan surat elektronik (UNESCO, 2002).

Menurut Mulyasa (2010) sumber belajar adalah rujukan, objek, dan bahan yang digunakan untuk kegiatan pembelajaran, sedangkan menurut AECT (Assosiation for Educational Communications and Technology) dan Banks dalam Komalasari (2010:108) menyatakan sumber belajar adalah segala sesuatu atau daya yang dapat dimanfaatkan oleh guru, baik secara terpisah maupun dalam bentuk gabungan, untuk kepentingan belajar mengajar.

Penggunaan TIK sebagai media pembelajaran dapat melalui pemanfaatan perangkat komputer sebagai media pembelajaran yang inovatif. Diharapkan dengan penggunaan media ini dapat merangsang pikiran, perasaan, minat serta perhatian peserta didik sedemikian rupa sehingga proses pembelajaran dapat berjalajan dengan baik. Selain itu, proses pembelajaran akan lebih efektif karena penggunaan TIK sebagai media pembelajaran memungkinkan teratasinya hambatan dalam proses komunikasi guru dengan peserta didik seperti hambatan fisiologis, psikologis, kultural, dan lingkungan.

Pemanfaatan teknologi dan komunikasi dalam bidang pendidikan menurut Munir (2009, pemanfaatan komputer dan jaringan komputer memberikan kesempatan kepada setiap pembelajaran untuk mengakses materi pembelajaran yang disajikan dalam bentuk interaktif melalui jaringan komputer.

Ksususnya di sekolah dasar di kelas rendah (kelas 1, 2 dan 3) penggunaan TIK sangat membantu sekali dalam hal penyampaian materi, dengan menggunakan visualisasi dan animasi diharapkan dapat meningkatkan pemahaman peserta didik. Selain itu guru sekolah dasar merupakan guru kelas yang harus menguasai seluruh mata pelajaran terkecuali mata pelajaran agama dan penjas. Dengan begitu guru sekolah dasar harus lebih kreatif dan inovatif dikarenakan berbedanya karakteristik dari setiap mata pelajaran.

Jenis-jenis sumber dan media pembelajaran berbasis TIK yang dapat dimanfaatkan oleh guru sekolah dasar dalam proses pembelajaran anatara lain:
1. Komputer
2. LCD
3. Internet
4. CD Pembelajaran 
5. E-mail

6. Persentasi Power Point

\section{Kompetensi Penguasaan TIK Bagi Guru Sekolah Dasar}

Kompetensi adalah tindakan atau kinerja yang menggambarkan potensi, pengetahuan, keterampilan, dan sikap, yang terkait dengan profesi tertentu (Rivalina, 2014). Yang menjadi fokus pada artikel ini mengenai kompetensi guru dalam bidang TIK. Kompetensi guru dalam bidang TIK yang dimaksud adalah kemampuan guru dalam hal menguasai dan mengembangkan pembelajaran dengan menggunakan perangkat TIk. Menurut Peraturan Menteri Pendidikan Nasional Nomor 16 Tahun 2007, kompetensi TIK bagiguru sekurang-kurangnya mempunyai dua fungsi, yaitu TIK sebagai pengembangan diri dan TIK sebagai penunjang proses pembelajaran (Niarsa, 2013).

\section{Menurut Wijayanti (2011) Standar}

Kompetensi Guru yang harus dikuasai dalam penguasaan TIK adalah :

1. Mengoperasikan komputer personal dan periferalnya (perangkat pendukung).

2. Merakit, menginstalasi, menset-up, memelihara dan melacak serta memecahkan masalah (troubleshooting) pada komputer personal

3. Melakukan pemrograman komputer dengan salah satu bahasa pemrograman berorientasi objek.

4. Mengolah kata ( word processing) dengan komputer personal
5. Mengolah lembar kerja (spreadsheet) dan grafik dengan komputer personal

6. Mengelola pangkalan data (data base) dengan komputer personal atau komputer server

7. Membuat presentasi interaktif yang memenuhi kaidah komunikasi visual dan interpersonal.

\section{Kendala Penggunaan TIK Di Dekolah Dasar}

Menurut Aka, Kukuh A. (2017).beberapa kendala penggunaan TIK di Sekolah dasar anata lain:

1. Pengembangan software perangkat pembelajaran berbasis TIK masih relatif mahal. Guru kelas hendaknya memanfaatkan software perangkat pembelajaran berbasis TIK yang diberikan secara gratis oleh pemerintah atau mendownload dari internet sendiri.

2. Memerlukan pengetahuan dan keterampilan pemrograman untuk mengembangkan bahan ajar/software pembelajaran berbasis TIK. Tidak semua guru kelas memiliki kemampuan bahasa pemrograman. Oleh karena itu, diharapkan guru kelas dapat memanfaatkan software perangkat pembelajaran yang sudah siap pakai.

3. Program yang tersedia saat ini belum memperhitungkan kreativitas siswa, sehingga hal tersebut tentu tidak akan dapat mengembangkan kreativitas siswa. Guru perlu menggabungkan 
pembelajaran berbasis TIK dengan tetap tidak meninggalkan aktivitas yang mengembangkan keterampilan siswa.

4. Mengurangi interaksi antara pengajar dan siswa atau bahkan antara siswa itu sendiri. Guru perlu menggabungkan pembelajaran berbasis TIK dengan tetap tidak meninggalkan aktivitas interaksi siswa antar siswa dan siswa dengan guru.

5. Proses pembelajarannya cenderung ke arah pelatihan dari pada pendidikan. Pendidikan yang bersifat mengajarkan perilaku, moral, dan nilai tetap memerlukan interaksi dengan manusia lainnya.

6. Meski keberadaannya sudah semakin luas, tidak semua tempat tersedia fasilitas internet, komputer, dan jaringan perlistrikan.

7. Semakin canggihnya peralatan TIK, dapat dimungkinkan terjadi penyalahgunaan dibidang pendidikan.

\section{Solusi Meningkatkan Kemampuan Penguasaan TIK Bagi Guru}

Menurut Mugara (2011) Sebagai solusi dalam hal meningkatkan kemampuan penguasaan TIK bagi guru dapat dilakukan beberapa hal sepaerti yang diungkapkan anatara lain, seperti:

1. Mengirim guru untuk mengikuti kegiatan pelatihan, penataran, seminar dan workshop mengenai TIK.
2. Mengadakan kegiatan pelatihan dan sosialisasi TIK bagi seluruh guru dengan mendatangkan nara sumber ahli.

3. Melengkapi berbagai sarana dan media berbasis TIK yang dapat menunjang kegiatan pembelajaran.

4. Melaksanakan dan melatih pembelajaran dengan menggunakan berbagai strategi dan metode berbasis TIK, meskipun tidak semua sekolah mampu melaksanakan secara efektif.

5. Mengadakan studi banding ke sekolah lain yang dipandang lebih maju bidang TIKnya.

\section{SIMPULAN}

Penggunaan TIK sebagai sumber dan media pembelajaran dapat melalui pemanfaatan perangkat komputer sebagai sumber dan media pembelajaran yang inovatif. Diharapkan dengan penggunaan sumber dan media ini dapat merangsang pikiran, perasaan, minat serta perhatian peserta didik sedemikian rupa sehingga proses pembelajaran dapat berjalajan dengan baik. Selain itu, proses pembelajaran akan lebih efektif karena penggunaan TIK sebagai sumber dan media pembelajaran memungkinkan teratasinya hambatan dalam proses komunikasi guru dengan peserta didik.

Standar Kompetensi Guru yang harus dikuasai dalam penguasaan TIK antara lain: (1) Mengoperasikan komputer personal dan periferalnya (perangkat pendukung), Merakit, menginstalasi, menset-up, memelihara dan melacak serta memecahkan 
masalah (troubleshooting) pada komputer personal, (3) Melakukan pemrograman komputer dengan salah satu bahasa pemrograman berorientasi objek,

Mengolah kata ( word processing) dengan komputer personal, (5) Mengolah lembar kerja (spreadsheet) dan grafik dengan komputer personal, (6) Mengelola pangkalan data (data base) dengan komputer personal atau komputer server, (7) Membuat presentasi interaktif yang memenuhi kaidah komunikasi visual dan interpersonal.

\section{DAFTAR PUSTAKA}

Aka, Kukuh A. .(2017). Pemanfaatan Teknologi Informasi dan Komunikasi (TIK) Sebagai Wujud Inovasi Sumber Belajar Di Sekolah Dasar, (Online). Diakses dari http://journal.umsurabaya.ac.id/index.php/pgsd/article/vi ew/1041.

Batubara, Delia S. .(2017). Kompetensi Teknologi Informasi dan Komunikasi Guru SD/MI (Potret, Faktor-faktor, dan Upaya Meningkatkannya), (Online). Diakses dari https://media.neliti.com/media/publicati ons/222457-kompetensi-teknologiinformasi-dan-komun.pdf.

Komalasari, Kokom. .(2010). Pembelajaran Kontekstual. Konsep dan Aplikasi. Bandung: Refika Aditama.

Mugara, R. .(2011). Meningkatkan kompetensi guru melalui penguasaan teknologi informasi dan komunikasi (TIK). Prodi Pengembangan Kurikulum. Universitas Pendidikan Indonesia. Sunan Kalijaga: Yogyakarta
Mulysa. .(2010). Kurikulum Tingkat Satuan Pendidikan. Bandung : PT Remaja Rosdakarya

Munir. .(2009). Pembelajaran Jarak Jauh Berbasis Teknologi Informasi dan Komunikasi. Bandung: Alfabeta.

Niarsa, A. .(2013). Studi Kompetensi Guru Dalam Memanfaatkan Media Pembelajaran Berbasis Teknologi Informasi Dan Komunikasi (TIK) DI SD Negeri 01 Ledok Kecamatan Sambong Kabupaten Blora. Universitas Negeri Semarang.

Rivalina, R. .(2014). Kompetensi Teknologi Informasi dan Komunikasi Guru dalam Peningkatan Kualitas Pembelajaran. Jurnal Teknodik, 18(2), 165-176

Rusman, dkk. .(2011). Pembelajaran Berbasis Teknologi Informasi dan Komunikasi. Jakarta: Rajagrafindo Persada.

Unesco. (2002). Teknologi Komunikasi dan Informasi dalam Pendidikan : kurikulum dan untuk sekolah dan program pengembangan guru. Alih Bahasa Rusli: Gaung Persada Press.

Wijayanti, Inggit D. .(2011). Peningkatan Pendidikan Berbasis ICT. 